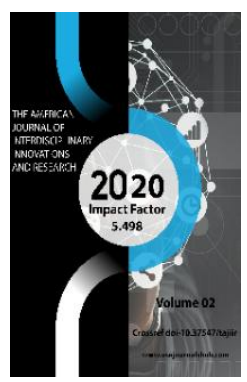

\title{
Dialectics Of Information Culture And Creative Thinking
}

\author{
Odil Fayzullaevich Boynazarov, \\ Scientific Researcher Of The Samarkand State University, Samarkand, Uzbekistan
}

Journal Website: http://usajournalshub.c om/index,php/tajiir

Copyright: Original content from this work may be used under the terms of the creative commons attributes 4.0 licence.

\section{ABSTRACT}

This article discusses the relationship between information culture and the dialectic of creative thinking in today's evolving world. At the same time, comments were made on the correct acceptance and adequate implementation of the information culture in the field of creative thinking, which emerged in the era of innovative technologies and communications. The importance of the development of information culture in the life and development of society is discussed in detail.

\section{KEYWORDS}

Man, information, dialectics, creativity, creative thinking, information culture, society, renewal, development, science.

\section{INTRODUCTION}

Mankind has been in constant contact with the external environment, that is, the collection and transmission of all-round information has been carried out continuously. We know from history that in ancient times it took a long time to receive or transmit certain information. From the point of view of time, as a result of creativity in human thinking, the emergence of innovative ideas and their application in practice, inventions and discoveries at the level of the human imagination were presented to the 
public and had a huge impact on the development of countries. Nowadays, new innovative media are being discovered in a matter of seconds. In this day and age of development, the media is becoming increasingly important. Today, in-depth study of innovative techniques and technologies in the field of creative thinking, access to an informed society, the ability to use the benefits of the virtual world in the right way can form a comprehensive information culture in society. Before forming an information culture in the external environment, we need to know and analyze the essence of the word "information". So, "information" means "information" in Latin. Information: 1. Information that people give to each other orally, in writing or otherwise. It also understands the process of giving and receiving information. 2 . The concept of science and technology. This concept includes not only information between people, but also information between man and machine, between machine and machine (in cybernetics), the exchange of signals between animals and plants.

Since the 1950s, attempts have been made to use the concept of information in describing various events and processes. [1]

"Let's try to bring computers, information technology, the Internet in general, not only to industry and production, but to our whole lives." [2, 207]

At present, in New Uzbekistan, on the basis of world standards, innovative techniques and technologies are widely used in any field, economic, political, social and educational. In the words of our President Sh. Mirziyoev: "Today we are moving on the path of innovative development aimed at radical renewal of all spheres of life of the state and society. This is not in vain, of course, because who will win in today's fast-paced world? A state based on new ideas, new notions and innovations will win. " $[3,20]$

\section{METHODS AND MATERIALS}

In the philosophy of the present time, creative thinking is also associated with a new postnonclassical scientific thought, which is formed.

At the end of the last quarter of the twentieth century, appeared new scientific directions such as synergy, nanoscience, global evolutionism, cycology, the theory of dissipative structures. These new directions, originated in the system of sciences, are making fundamental changes in the meaning of scientific way of thinking and methodology of science. In particular, spiritual ideological foundations of social and biological sciences and the humanities are updating, under the influence of this process, we can say, postnonclassical scientific worldview is generating. [4.21]

Humans have created an information culture in society through the comprehensive use of the virtual world and innovative information technologies. Information culture means the ability to conduct purposeful activities with information and use innovative information technologies to collect process and transmit information. Information culture is a part of general culture, and information culture is a process that leads people to find a reasonable and purposeful way in the information and virtual world. As the information culture develops, so does the information society, that is, the information system and the virtual world no longer have a small number of inexperienced people, but the ability to perceive in the context of creative thinking, technology. , a group of people with high skills and abilities, as well as strong innovative 
abilities in the world of the Internet, have created an information society. If we explain this process from the point of view of "Dialectics" science, it is compared with the "Law of transition of quantitative change to qualitative change". Regarding the information society, Japanese scientists agree that the process of computerization in an information society allows people to use a reliable information culture, provide a high degree of automation of information processing in production and social spheres. The driving force in the development of society should be the production of information, not material products. In an informed society, intellectual knowledge with creative potential is produced, sold and consumed. Consumption of information is a process that satisfies spiritual needs, fills the spiritual gap. At the same time, of course, there are people who use the system of the virtual world for unjustified purposes, acting in violation of the laws of information culture.

Such events are widely observed today with the younger generation. We can cite a number of good reasons for our young people to disseminate or consume information that is not in demand in the information system, which is transmitted and sold to the Internet in general, and which contradicts our national values and the law, namely:

1. Incorrect distribution;

2. Unhealthy family environment, lack of parental attention to the child;

3. Low thinking capacity, as well as dependence on the opinions of others;

4. Excessive interest in material wealth among young people, inability to satisfy their desires, and so on.

It should not be forgotten that even a small message against human spirituality, which at first glance seems insignificant, is strengthened by the intensity of globalization in the world of information. It can cause enormous damage that cannot be covered by anything. [5.75]

\section{RESULTS}

Unusually creative thinkers are constantly searching for their own way to realize their destiny, and as a result, they are among the happiest people on earth who have achieved their goals. [6. 13] Creative thinking is an unconventional way of thinking formed in the period of industrial and post-industrial, scientific and technological revolutions and rapid growth, progress of societies and enriching new stages of technical development in modern societies with human resources. Thinking aimed at ensuring the factors of ability and development.

Creativity and creativity perform the function of innovative thinking. Innovative thinking has the feature of ijdoiot science, which is the direction of research. The main task of creativity is to build a model of the new search process for a particular system, giving the same process details.[7.172]

The owners of any creative informationminded information society today have their own powerful spiritual weapon. Creativity means independent thinking. Everyone must be able to think independently and analyze it sufficiently in order to achieve certain knowledge. As the famous Chinese philosopher Confucius said, "Knowledge without thinking is futility, and thinking without knowledge is dangerous." [8] Everyone has a certain place in society through the level of thinking and knowledge. The fundamental knowledge acquired by mankind throughout his life will accompany him until the end of his life. 


\section{CONCLUSION}

Based on the above, we come to the following conclusions:

Firstly: In this information age and society, the life of each of us is inextricably linked with innovative technologies. At a time when our lives are unimaginable without innovative technologies and the Internet, it is important not to be preoccupied with the search for flaws in the network, but to use its positive opportunities to spread the glory of our country around the world, as well as to meet our needs.

Secondly: Today, representatives of any industry need to study techniques and technologies in depth, as well as to develop the ability to innovate. Because, at the same time, the inability to adapt to the requirements of the times causes a person to be one step behind in various fields.

Third: It would be expedient for everyone to develop the ability to think creatively. Because a person with the ability to think creatively, can speak in a way that is unusually wider and clearer than those around him, and will have a high status in life.

\section{REFERENCES}

1. uz.m.wikipedia.org.

2. Karimov I.A. Each of us is responsible for the development of the country. T.: “Uzbekistan”, 2001. - P. 275.

3. Speech by the President of the Republic of Uzbekistan Shavkat Mirziyoyev on December 22, 2017 in his Address to the Oliy Majlis. T.: “Uzbekistan”. NMIY, 2018. P. 20.
4. Allamuratov Sh.A. Collection of lectures on the basics of globalization. Termez. 2014, P. 191.

5. Teresa M., Amabayl. Creative thinking in business/ Per.s angl. -M.: Alpina Business Box. Series "Classic Harvard Business Review”, 2006. - P. 228.

6. www.kh-davron.uz. Confucius Wisdoms \& Confucius. The Book of Proverbs. (2010). Khurshid Davron Library.

7. Sultanova, G. S. (2020). SCIENTIFIC THINKING: INNOVATION AND INNOVATION ACTIVITIES. In Современная наука: новые подходы и актуальные исследования (рр. 170-173).

8. Sultanova, G. S. (2019). The essence and nature of postnonclassical scientific thinking. Школа Науки, (3), 21-22.

9. Gulnoza, Sultanova (2019) "SCIENCE IN THE HADITHSS: HISTORY AND TIMES," Uzbekistan Journal of Oriental Studies: Vol. 1 : Iss. 2 , Article 12.Available at: https://uzjournals.edu.uz/or_stud/vol1/iss2/1 2 